\title{
REVIEW
}

\section{Mucosa-associated lymphoid tissue (MALT) lymphoma: a practical guide for pathologists}

\author{
Chris M Bacon, Ming-Qing Du, Ahmet Dogan
}

J Clin Pathol 2007;60:361-372. doi: 10.1136/icp.2005.031146

Extranodal marginal zone lymphoma of mucosa-associated lymphoid tissue (MALT lymphoma) is the third most common non-Hodgkin lymphoma subtype, accounting for around 6-8\% of all non-Hodgkin lymphomas in the Western hemisphere. Although MALT lymphomas are clinically indolent, the disease is typically chronic, requiring long-term clinical surveillance and, often, repeated biopsies. Pathologists thus play a central role in the diagnosis and management of these patients. The optimal diagnosis and management of a MALT lymphoma requires careful integration of morphological, immunohistochemical and molecular information, together with close cooperation with the clinician treating the patient. This review discusses recent developments in the molecular pathogenesis of MALT lymphoma and provides strategies for integrating this information into daily pathological practice.

See end of article for authors' affiliations

Correspondence to: Professor A Dogan, Mayo Clinic, 200 First Street SW, Rochester, MN 55905, USA; dogan.ahmet@mayo. edu

Accepted 31 July 2006 Published Online First 1 September 2006
O ur understanding of the aetiology and molecular pathogenesis of MALT lymphoma has exploded in recent years. In the last 5 years, over 1000 peer-reviewed papers on MALT lymphoma have been published in the scientific literature, and approximately 200 of these have been devoted to the study of the molecular events in this disease. Although there have been several elegant reviews on the molecular pathology of MALT lymphoma, ${ }^{2}$ there is little practical information on the relevance of these findings to the work of surgical pathologists. The aim of this review is to provide such practical information and suggest guidelines to integrate the recent developments in the field into routine diagnostic histopathological practice.

\section{AETIOLOGY}

A number of infections have been implicated in the development of MALT lymphoma. The most firmly established association is that between gastric Helicobacter pylori infection and gastric MALT lymphoma. ${ }^{34}$ It appears that $H$ pylori is critical for lymphomagenesis and also creates a microenvironment favouring the growth of neoplastic B cells, probably through the help of $\mathrm{T}$ cells. ${ }^{56}$ Eradication of $H$ pylori by antibiotic treatment leads to regression of gastric MALT lymphoma in around $75 \%$ of cases and has become established clinical practice. Other associations between MALT lymphoma and infectious agents include Chlamydia psattici and ocular adnexal MALT lymphoma, ${ }^{7}$ hepatitis $\mathrm{C}$ virus and salivary gland MALT lymphoma, ${ }^{8}$ and $C$ jejuni and immunoproliferative small intestinal disease. ${ }^{9}$ There is recent evidence suggesting that eradication of C psattici infection may lead to regression of ocular adnexal MALT lymphoma ${ }^{10}$; however, this association remains controversial. ${ }^{11} 12$

Currently, in daily clinical practice, only detection of $H$ pylori infection has clinical value. In tissue sections this can be achieved by a number of methods, of which immunohistochemistry is thought to be the most specific and sensitive. ${ }^{13}$

\section{HISTOLOGICAL DIAGNOSIS}

\section{Characteristic morphological features}

MALT lymphomas arising at different anatomical sites nevertheless share common morphological features. ${ }^{14-16}$ The neoplastic cells infiltrate around reactive secondary lymphoid follicles in a marginal zone distribution and spread outwards to form diffuse interfollicular sheets or, in some cases, a vaguely nodular pattern. Although diagnostically helpful, identification of reactive follicles is not required for diagnosis as they may not be present in the small biopsy specimens often submitted for assessment. The lymphoma cells assume varied cytological appearances, often within individual specimens. Characteristic are centrocyte-like cells, which are small to medium-sized cells with small irregular nuclei. Alternatively, the neoplastic cells may have a monocytoid appearance with abundant pale cytoplasm and distinct cell borders, or may resemble small mature lymphocytes (fig 1). Scattered large transformed centroblast- or immunoblast-like cells are usually dispersed throughout the lymphoma. Variable numbers of plasma cells are frequently present, often adjacent to the epithelium. In approximately one-third of cases these are part of the neoplastic clone, and may show atypical features such as Dutcher bodies. In some cases, particularly in the thyroid gland, plasma cells may be so numerous as to suggest an extramedullary plasmacytoma.

An important diagnostic feature of MALT lymphoma at many sites is the presence of lymphoepithelial lesions, defined by the infiltration and distortion of epithelial structures by aggregates of (usually three or more) neoplastic lymphoid cells $^{14}$ (figs 1A, 2B). The affected epithelium often shows degenerative changes such as cellular swelling and eosinophilia, and, if

Abbreviations: $D L B C L$, diffuse large $B$ cell lymphoma; FDC, follicular dendritic cell; FISH, fluorescence in situ hybridisation; FOX, forkhead box; MALT, mucosaassociated lymphoid tissue; NF, nuclear factor; pMRD, probable minimal residual disease 


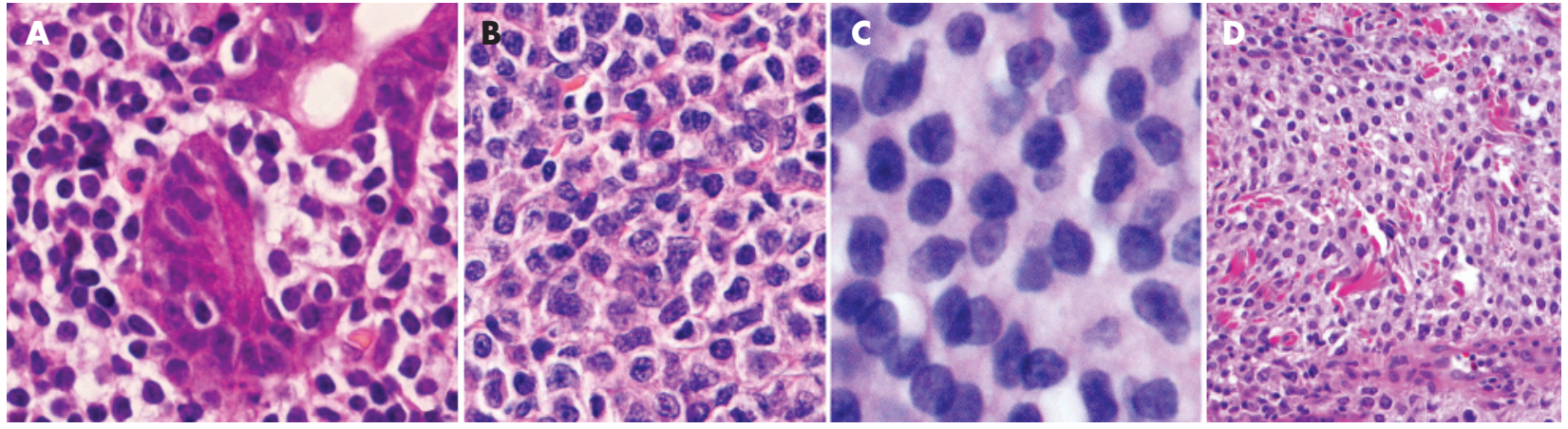

Figure 1 Cytological spectrum of neoplastic B cells in mucosa-associated lymphoid tissue lymphoma. (A) Small lymphoid cells with a narrow rim of clear cytoplasm forming lymphoepithelial lesions (H\&E). (B) Centrocyte-like cells (H\&E). (C) Small lymphoid cells with condensed chromatin reminiscent of mantle cell lymphoma (H\&E). (D) Monocytoid cells with abundant clear cytoplasm (H\&E).

infiltration is extensive, may disintegrate, leaving only clusters of degenerate cells among the lymphoid infiltrate. The presence of individual (non-clustered) small lymphocytes within the epithelium is insufficient for designation as a lymphoepithelial lesion, as such infiltration may occur by B cells in the normal lymphoepithelium of MALT, or by $\mathrm{T}$ cells in many reactive conditions. It is also important to note that lymphoepithelial lesions may be formed by lymphomas other than MALT lymphomas and that, although highly suggestive of MALT lymphoma if present in the context of a small lymphocytic proliferation, lymphoepithelial lesions can be seen occasionally in inflammatory states including florid gastritis and reactive pulmonary infiltrates.

\section{Immunohistological features}

The immunophenotype of the neoplastic cells of MALT lymphoma is virtually identical to that of non-neoplastic marginal-zone B cells: CD20+, $\operatorname{IgD}-, \operatorname{Ig} M(>\operatorname{Ig} A>\operatorname{IgG})+$, CD5-, CDl0-, Bcl6-, cyclin Dl-. ${ }^{15}$ No specific immunohistochemical marker has yet been identified for MALT lymphoma, but evaluation of a panel of immunostains is necessary for assessment of the architecture of the lymphoid infiltrate, lineage assignment, identification of an aberrant phenotype or immunoglobulin light-chain restriction, and for the exclusion of other lymphomas. The presence of an extensive, dense, diffuse infiltrate of CD20+ B cells (with or without admixed CD3 $\mathrm{T}$ cells) between glands and reactive follicles is highly suggestive of lymphoma. Staining for CD21 and CD10 can be helpful in identifying unrecognised lymphoid follicles, often with expanded follicular dendritic cell (FDC) meshworks, whereas staining for IgD can demonstrate intact follicular IgD+ mantle zones, beyond which the IgD - neoplastic marginal zone cells are distributed (fig 2). Staining for cytokeratin can reveal lymphoepithelial lesions or scattered epithelial cell remnants. Demonstration of immunoglobulin light chain restriction is extremely helpful in the exclusion of a reactive lymphoid infiltrate; if there is plasma cell differentiation, light chain restriction may be demonstrable especially, or only, in plasma cells. In approximately 50\% of MALT lymphomas, there is aberrant co-expression of CD43 by CD20+ small B cells, a phenotype strongly suggestive of lymphoma (fig 3). Demonstration of negativity of the lymphoma cells for IgD, CD5, CD10, Bcl6 and cyclin D1 can help to exclude other small B cell lymphomas. Very occasional MALT lymphomas may express $\mathrm{CD} 5$ or $\mathrm{IgD}^{17}{ }^{18}$; careful review of these cases, particularly to exclude a mantle cell lymphoma, is important. The MIB-1 proliferation fraction is low in lymphoma cells, but high in interspersed reactive follicles.

\section{Histological features of MALT lymphoma at commonly involved sites}

\section{Gastric MALT lymphoma}

Most gastric MALT lymphomas arise in patients in whom gastroscopy showed non-specific features such as inflammation, superficial erosions or ulceration, and are thus unanticipated. The most frequent problem in the diagnosis of gastric MALT lymphoma is its differentiation from $H$ pylori-associated gastritis. Among the histological features favouring MALT lymphoma are a dense lymphoid infiltrate occupying most of the biopsy fragment, prominent lymphoepithelial lesions, Dutcher bodies in plasma cells, infiltration of muscularis mucosae and moderate cytological atypia of lymphoid cells. ${ }^{19}$ Nevertheless, many endoscopic biopsy specimens lack several of these features. In 1993, Wotherspoon $e t a l^{20}$ proposed a useful scoring system to relate morphological findings to the likelihood of a lymphoid infiltrate being a gastric MALT lymphoma (table 1). More recently, the incorporation of immunohistological and molecular genetic assessment alongside histological examination has resulted in an increase in the confidence with which a MALT lymphoma can be diagnosed or excluded in gastric biopsies. An integrated diagnostic approach to gastric lymphoid infiltrates is presented in more detail below.

\section{Pulmonary MALT lymphoma}

MALT lymphomas of the lung typically present with single or multiple radiologically detected pulmonary nodules or consolidations, either in asymptomatic patients or in patients with nonspecific respiratory complaints such as cough and dyspnoea. ${ }^{21} 22$ The lymphoma characteristically shows a lymphangitic pattern of infiltration, spreading along bronchovascular bundles, interlobular septa and visceral pleura, coalescing to form destructive masses which efface the pulmonary parenchyma (fig 4). This architecture, together with the extension of B cells beyond the confines of reactive lymphoid follicles, helps to distinguish MALT lymphoma from follicular bronchiolitis, lymphoid interstitial pneumonia and nodular lymphoid hyperplasia. Lymphoepithelial lesions are formed with the bronchial and bronchiolar epithelium, but these are not specific for lymphoma. Other features often seen in pulmonary MALT lymphomas include fibrosis, nonnecrotising transmural infiltration of large blood vessels, noncaseating granulomas, amyloid/immunoglobulin deposition often associated with foreign body-type giant cells and giant lamellar bodies formed at least in part from surfactant protein. ${ }^{21}{ }^{23}$

MALT lymphoma of the salivary glands

Most salivary gland MALT lymphomas arise on a background of myoepithelial sialadenitis/benign lymphoepithelial lesion. When fully developed, this comprises atrophic acinar tissue 


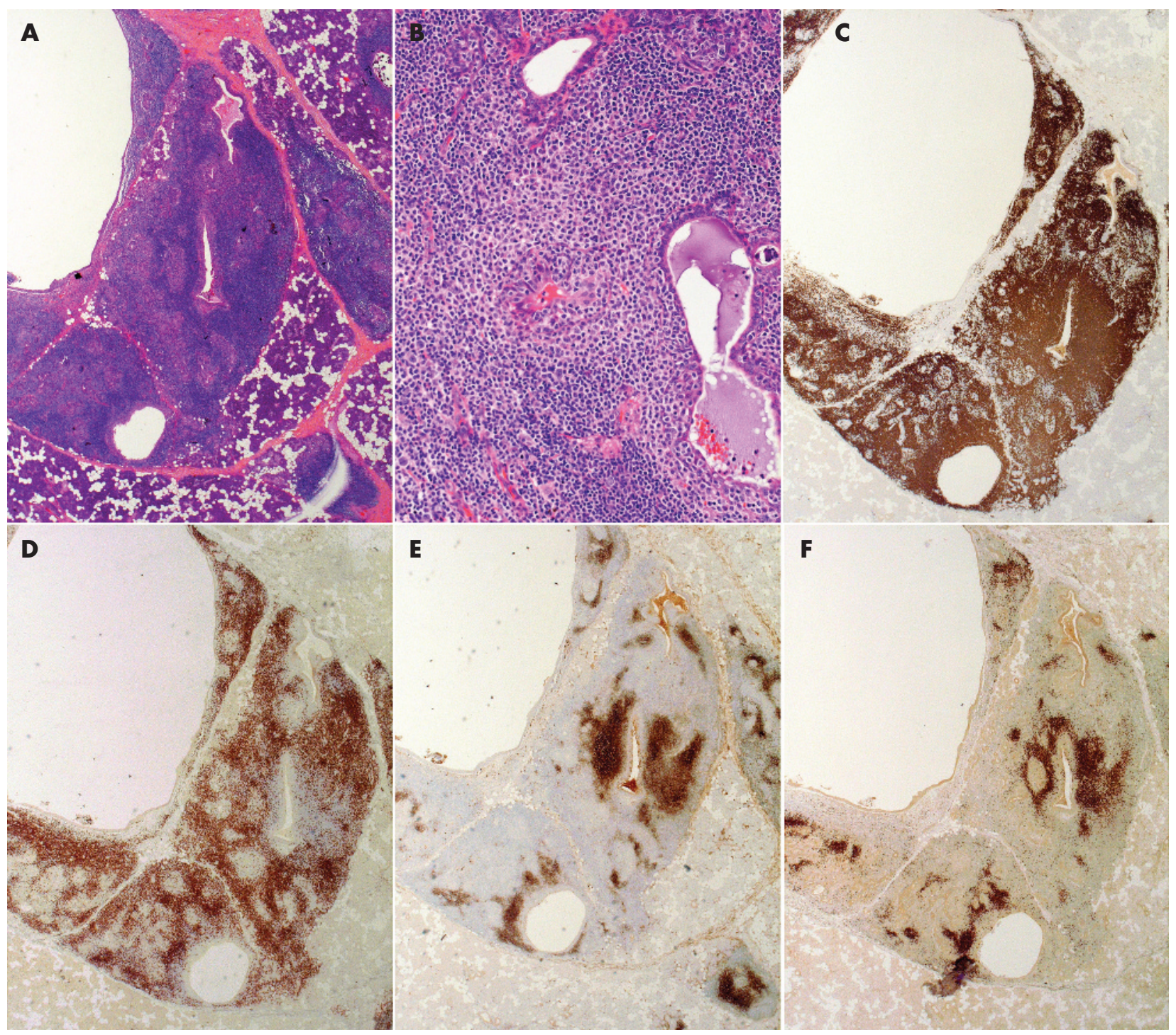

Figure 2 Typical immunoarchitecture of mucosa-associated lymphoid tissue (MALT) lymphoma involving the parotid gland. (A) The gland is heavily infiltrated by lymphoid cells. Although most of the infiltrate is diffuse, a few reactive follicles with well-defined mantle zones are apparent. Note the cystic dilatation of some of the ducts, a phenomenon frequently seen in parotid MALT lymphoma (H\&E). (B) The lymphoid cells with "monocytoid" cytology form a halo around the ducts and infiltrate into the duct epithelium (H\&E). (C) CD20 staining highlights the extensive B cell infiltrate particularly around ducts (immunoperoxidase). (D) There is also a significant interstitial infiltrate of CD3-positive T cells, a characteristic feature of MALT lymphoma (immunoperoxidase). (E) CD21 staining demonstrates the follicular dendritic cell meshwork underlying the follicular architecture of the tumour (immunoperoxidase). (F) MALT lymphomas, like a subset of normal memory/marginal-zone cells, are typically lgM positive and lgD negative. IgD staining highlights residual normal mantle zone B cells surrounding the follicles. When compared with panel $C$, a vast majority of the B cells occupying the marginal zone of reactive follicles are lgD negative. This is a very helpful tool in the diagnosis of MALT lymphoma (immunoperoxidase).

infiltrated by small lymphocytes and plasma cells, often with reactive lymphoid follicles, and characteristically with numerous epimyoepithelial islands. The epimyoepithelial islands are solid islands of proliferated ductal epithelium infiltrated by small B lymphocytes. The first morphological manifestation of the emergence of a MALT lymphoma is the presence of haloes or collars of pale monocytoid B cells around the epimyoepithelial islands. ${ }^{24}$ Such infiltrates usually show immunoglobulin light chain restriction, and in their presence a clonal B cell population can be usually demonstrated by PCR. ${ }^{25}$ Nevertheless, because of their indolent behaviour, some consider such lesions to be borderline. ${ }^{26}$ More established MALT lymphomas are characterised by expansile, often destructive, proliferations of neoplastic marginal zone B cells, "cavitating" lymphoepithelial lesions and gradual replacement of reactive follicles. Dilatation of ducts may result in a cystic appearance.

The specific features of MALT lymphoma in the ocular adnexa, skin and thyroid gland have been described elsewhere. ${ }^{14}$ 27-30

\section{Areas of diagnostic difficulty}

Large B cells and diffuse large B cell lymphoma

The number of individually disposed large transformed blasts present in typical MALT lymphomas varies from case to case (up to approximately $10 \%$ of all cells). Whether this variation is of prognostic significance is controversial and is discussed below. MALT lymphomas may undergo transformation to frank large-cell lymphoma, which may be present at diagnosis. When 


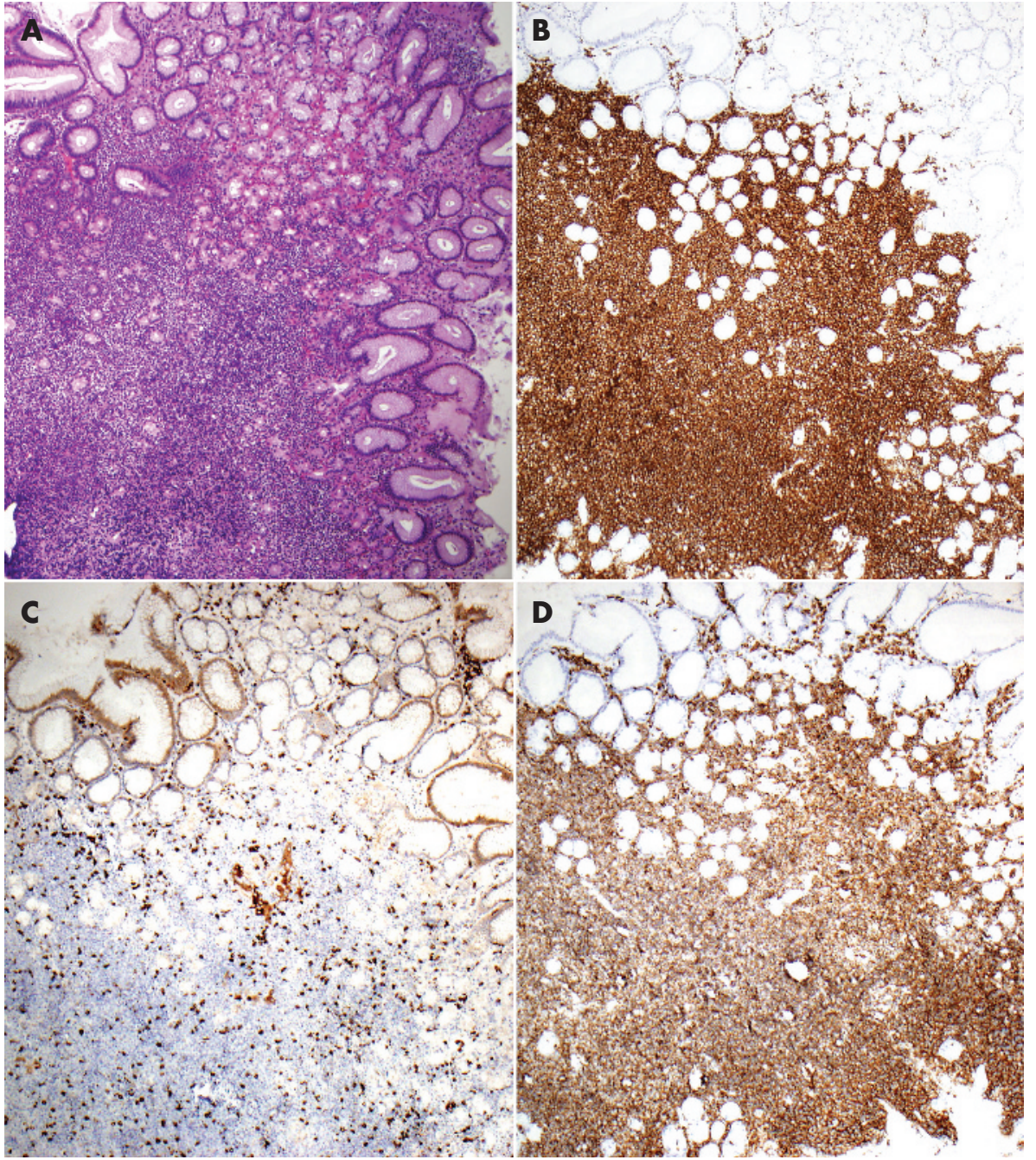

Figure 3 Aberrant CD43 expression is a very useful tool for histological diagnosis of mucosa-associated lymphoid tissue (MALT) lymphoma. (A) Low-power view of a gastric MALT lymphoma (H\&E). (B) CD20 highlights a diffuse infiltrate of neoplastic $B$ cells (immunoperoxidase). (C) CD3 is expressed by a small number of reactive $T$ cells (immunoperoxidase). (D) CD43 is strongly expressed by neoplastic B cells. As CD43 is also expressed by $T$ cells, this stain should always be interpreted in the context of a CD3 stain (immunoperoxidase). this occurs, large blasts are present in clusters (usually containing $>20$ large cells) or sheet-like proliferations either mixed among or separate from the small-cell component ${ }^{31}$

Table 1 Wotherspoon scoring system for scoring gastric lymphoid infiltrates ${ }^{20}$

\begin{tabular}{lll}
\hline Score Diagnosis & Histological features \\
\hline 0 & Normal & $\begin{array}{l}\text { Scattered plasma cells in lamina propria. No } \\
\text { lymphoid follicles }\end{array}$ \\
1 & $\begin{array}{l}\text { Chronic active } \\
\text { gastritis }\end{array}$ & $\begin{array}{l}\text { Small clusters of lymphocytes in lamina } \\
\text { propria. No lymphoid follicles. No } \\
\text { lymphoepithelial lesions }\end{array}$ \\
2 & $\begin{array}{l}\text { Chronic active } \\
\text { gastritis with florid } \\
\text { lymphoid follicle } \\
\text { formation }\end{array}$ & $\begin{array}{l}\text { Prominent lymphoid follicles with a } \\
\text { surrounding mantle zone and plasma cells. No }\end{array}$ \\
$\begin{array}{l}\text { Suspicious lymphoid } \\
\text { infiltrate, probably } \\
\text { reactive } \\
\text { Suspicious lymphoid } \\
\text { infiltrate, probably } \\
\text { lymphoma } \\
\text { MALT lymphoma }\end{array}$ & $\begin{array}{l}\text { lymphocytes that infiltrate diffusely in lamina } \\
\text { propria and occasionally into the epithelium } \\
\text { lymphoid follicles surrounded by marginal- } \\
\text { zone cells that infiltrate diffusely in lamina } \\
\text { propria and into the epithelium in small groups } \\
\text { Presence of dense diffuse infiltrate of marginal- }\end{array}$ \\
& $\begin{array}{l}\text { zone cells in lamina propria with prominent } \\
\text { lymphoepithelial lesions }\end{array}$ \\
\hline
\end{tabular}

MALT, mucosa-associated lymphoid tissue. (fig 5). Care must be taken not to confuse a reactive germinal centre with a small focus of diffuse large B cell lymphoma (DLBCL). The current World Health Organization recommendation is that cases showing transformation to large-cell lymphoma should be diagnosed as DLBCL, and the presence of accompanying MALT lymphoma should be noted. ${ }^{15}$ The term "high-grade MALT lymphoma" is confusing and should not be used. In the absence of at least a focus of unequivocal typical MALT lymphoma, distinction of transformed MALT lymphoma from DLBCL arising de novo is often impossible, particularly because the formation of lymphoepithelial lesions by DLBCL does not prove transformation from MALT lymphoma.

\section{Follicular colonisation}

The ability of MALT lymphoma cells to infiltrate interspersed reactive lymphoid follicles leads to a range of histological appearances which can cause considerable diagnostic uncertainty (fig 6). In the most common situation, centrocyte-like cells over-run the lymphoid follicles, leaving behind scattered germinal centre fragments and dispersed mantle-zone cells and resulting in a vaguely nodular appearance. ${ }^{32}$ Immunostaining for CD21 highlights the expanded FDC networks underlying the nodules in these cases. The neoplastic marginal zone cells may also selectively infiltrate, replace and expand germinal centres, resulting in an appearance that may mimic follicular lymphoma. ${ }^{32}{ }^{33}$ Differentiation from follicular lymphoma is aided by 


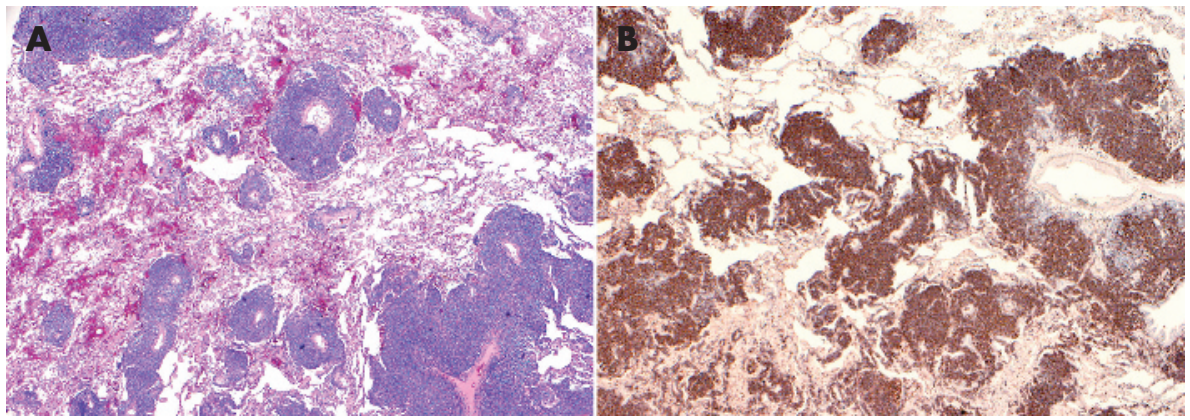

Figure 4 Typical low-power view of pulmonary mucosa-associated lymphoid tissue (MALT) lymphoma. (A) The lymphoid cells show a peri-lymphangitic pattern of infiltration (H\&E). (B) CD2O staining further highlights this pattern, which is virtually diagnostic of pulmonary MALT lymphoma (immunoperoxidase).

the demonstration that the neoplastic (eg, light chainrestricted) cells within the follicle centre lack markers of germinal centre origin (eg, CDl0 negative). In distinguishing colonised follicles from reactive follicles or from follicular lymphoma, it should be noted that the intrafollicular MALT lymphoma cells of colonised follicles may show either positive or negative staining for Bcl2. ${ }^{34}$ They are typically somewhat larger than the extrafollicular centrocyte-like cells, and may undergo frank blastic transformation or, rarely, show plasma cell differentiation.

\section{MOLECULAR PATHOLOGY IN DIAGNOSIS}

In some cases, although suspicious for MALT lymphoma, the morphological and immunohistological findings may be insufficient for a confident diagnosis. In such cases, the careful application of molecular biological techniques for the detection of B cell clonality or the identification of chromosomal abnormalities can be helpful.

\section{PCR-based analysis of B cell clonality}

Reliable PCR-based methods for the determination of B cell clonality in both fresh and formalin-fixed paraffin-embedded tissue are now routinely available. ${ }^{35-37}$ Most importantly, the availability of optimised PCR primers and protocols for the analysis of $I G H, I G K$ and $I G L$ gene rearrangement, developed by the European BIOMED-2 Concerted Action Program, now permits the sensitive, specific, practical and standardised detection of $\mathrm{B}$ cell clonality by any pathology laboratory. Approximately $80 \%$ of formalin-fixed paraffin-embedded tissue samples yield DNA suitable for BIOMED-2 analysis.

The utility of PCR in the diagnosis of MALT lymphoma has been examined most thoroughly in gastric biopsies. Using current techniques, monoclonal B cell populations are detected in approximately $80-90 \%$ of overt gastric MALT lymphomas. ${ }^{38} 39$ Similarly, the detection of unequivocal B cell monoclonality in a gastric biopsy showing morphological features suspicious for, but not diagnostic of, MALT lymphoma (ie, Wotherspoon score 4) strongly supports a diagnosis of MALT lymphoma. ${ }^{39}{ }^{40}$ Several groups, using in-house PCR protocols, have reported the detection of apparent B cell monoclonality in otherwise typical chronic gastritis, although in large series of unselected cases assessed using well-established methodology, clonal bands were detected in only $1-4 \%$ of such biopsies. ${ }^{39} 4142$ Further studies showed that this finding is associated with the presence of lymphoid follicles in the biopsy, ${ }^{43}$ suggesting that the clonal bands identified by PCR in many of these cases of gastritis result from the selective amplification of rearranged $I G H$ genes from an oligoclonal B cell population present within the few reactive

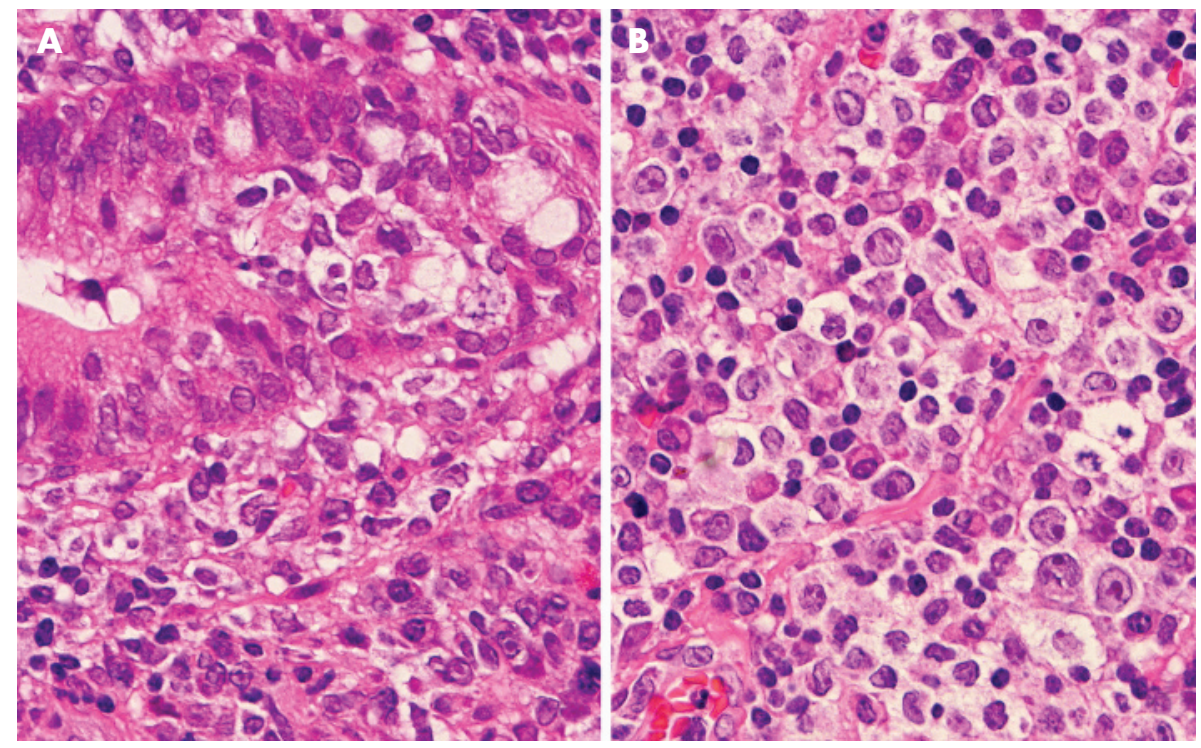

Figure 5 Mucosa-associated lymphoid tissue lymphoma and diffuse large B cell lymphoma in the colon. (A) The superficial part of the colonic mucosa contains a diffuse infiltrate of centrocyte-like cells forming lymphoepithelial lesions (H\&E). (B) The deeper part of the colonic mucosa contains sheets of large transformed immunoblasts consistent with diffuse large B cell lymphoma (H\&E). 


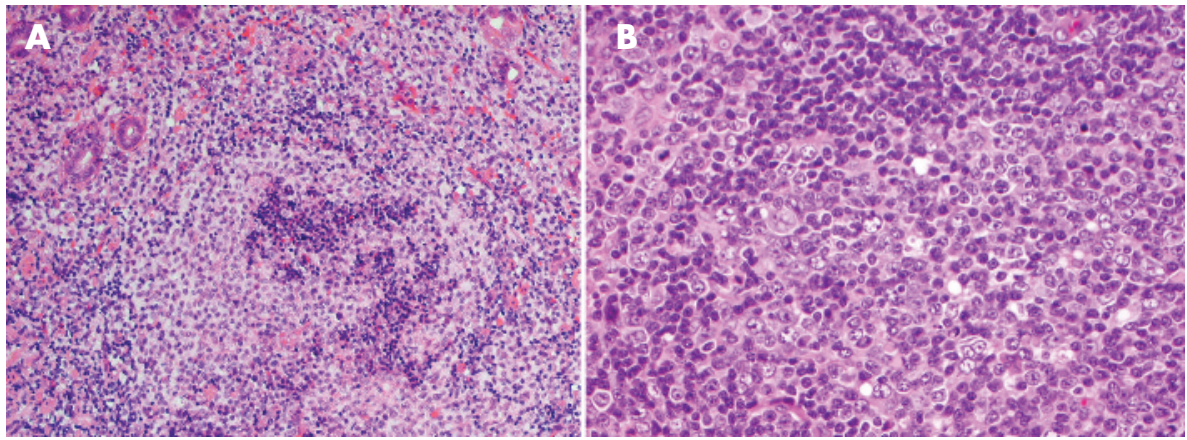

Figure 6 Follicular colonisation in mucosa-associated lymphoid tissue (MALT) lymphoma. (A) A gastric MALT lymphoma. The follicle is replaced by neoplastic B cells with monocytoid morphology. A rim of normal mantle zone is retained. (B) A salivary gland MALT lymphoma. In this instance, the follicle is partly infiltrated by a polymorphic population of neoplastic cells including monocytoid cells, transformed immunoblasts and plasma cells, which showed light-chain restriction.

germinal centres in the biopsy (pseudoclonality), and that particular care should be taken in the interpretation of such cases. PCR for $I G H$ gene rearrangement should be performed only when there is a lymphoid infiltrate morphologically suspicious of lymphoma, and MALT lymphoma should not be diagnosed in the absence of clear histological evidence. The role of B cell clonality analysis at other sites of MALT lymphoma is much less well studied. While analysing lymphoid infiltrates within salivary gland biopsies, Diss et $a l^{25}$ found that B cell monoclonality was highly correlated with the presence of morphological features of at least early MALT lymphoma. Others have reported B cell monoclonality in salivary gland tissue lacking such morphological features, ${ }^{26}{ }^{44}$ but it remains unknown whether these clones represent truly benign antigen-driven oligoclonal or monoclonal proliferations in the context of Sjögren's syndrome, clonal precursors to lymphoma or early lymphomas with indolent behaviour but with the potential for eventual dissemination (possibly following additional genetic alterations). ${ }^{45}$

\section{Detection of recurrent genetic abnormalities}

The three major translocations seen in MALT lymphomas are $\mathrm{t}(11 ; 18)(\mathrm{q} 21 ; \mathrm{q} 21) / A P I 2-M A L T 1, \mathrm{t}(14 ; 18)(\mathrm{q} 32 ; \mathrm{q} 21) / I G H-M A L T 1$ and $\mathrm{t}(1 ; 14)(\mathrm{p} 22 ; \mathrm{q} 32) / I G H-B C L 10$. Remarkably, these seem to promote lymphoma development by a common mechanism. This concordance results from the roles of both the adapter protein Bcllo and the caspase-like protein MALTl in the antigen receptor-mediated activation of nuclear factor (NF) $\mathrm{KB}-\mathrm{a}$ transcription factor that regulates the expression of genes involved in lymphocyte proliferation and survival. ${ }^{46}{ }^{47}$ In MALT lymphoma, the $\mathrm{t}(11 ; 18)(\mathrm{q} 21 ; \mathrm{q} 21)$ causes fusion of the genes for the inhibitor of apoptosis family member API2 and MALT1, resulting in the expression of an API2-MALT1 fusion protein, ${ }^{48-50}$ while the $\mathrm{t}(1 ; 14)(\mathrm{p} 22 ; \mathrm{q} 32)$ and $\mathrm{t}(14 ; 18)(\mathrm{q} 32 ; \mathrm{q} 21)$ result in the overexpression of $B C L 10$ and $M A L T 1$, respectively, as a result of juxtaposition with the $I G H$ enhancer. In each case, the resulting oncoproteins seem to act, at least in part, by aberrant activation of NFKB. ${ }^{51}$ Importantly, MALT lymphomas do not carry $\mathrm{t}(1 \mathrm{1} ; 14)(\mathrm{q} 13 ; \mathrm{q} 32) / I G H$-CYCLIN $D 1$ or $\mathrm{t}(14 ; 18)(\mathrm{q} 32 ; \mathrm{q} 21) / I G H-B C L 2$ translocations typical of mantle cell lymphoma or follicular lymphoma, respectively.

\section{$\dagger(11 ; 18)(q 21 ; q 21) / A P I 2-M A L T 1$}

The $\mathrm{t}(11 ; 18)(\mathrm{q} 21 ; \mathrm{q} 21)$ is the most common chromosomal translocation associated with MALT lymphoma, being found most often in gastric (approximately 25\% of cases) and pulmonary $(40 \%)$ cases, less often in ocular adnexal MALT lymphomas (5-15\%), and rarely in MALT lymphomas of the skin, salivary gland and thyroid gland..$^{52-55}$ The $\mathrm{t}(11 ; 18)(\mathrm{q} 21 ; \mathrm{q} 21)$ is not found in other small B cell lymphomas, and, as discussed below, is only very rarely identified in extranodal diffuse large B cell lymphomas..$^{56}$ Importantly, the translocation is not found in the inflammatory conditions which associate with or precede MALT lymphoma, including $H$ pylori-associated gastritis. ${ }^{57}$ When present, a $\mathrm{t}(11 ; 18)(\mathrm{q} 21 ; \mathrm{q} 21)$ is usually the sole chromosomal abnormality present; by contrast, MALT lymphomas without a $\mathrm{t}(11 ; 18)(\mathrm{q} 21 ; \mathrm{q} 21)$ frequently show aneuploidy, particularly trisomies 3 and $18 .^{58-60}$ The $\mathrm{t}(11 ; 18)(\mathrm{q} 21 ; \mathrm{q} 21)$ can be detected in formalin-fixed paraffin-embedded biopsy material with relative ease, by either interphase fluorescence in situ hybridisation (FISH) or reverse transcriptase-PCR assays ${ }^{61}{ }^{62}$ (fig 7). The finding that the $\mathrm{t}(11 ; 18)(\mathrm{q} 21 ; \mathrm{q} 21)$ is associated with moderately intense aberrant nuclear immunostaining for Bcllo is of potential interest. ${ }^{57}{ }^{63}$ However, this finding is of limited clinical utility as $20 \%$ of $\mathrm{t}(11 ; 18)(\mathrm{q} 21 ; \mathrm{q} 21)$-negative MALT lymphomas and some nonMALT lymphomas show a similar Bcll0 staining pattern, ${ }^{64}$ and the ability of laboratories to demonstrate such a staining pattern, particularly on small biopsies, is variable.

\section{$\dagger(14 ; 18)(q 32 ; q 21) / I G H-M A L T 1$}

The second most frequent translocation identified in MALT lymphoma is the $\mathrm{t}(14 ; 18)(\mathrm{q} 32 ; \mathrm{q} 21) / I G H-M A L T 1$. Although this translocation occurs at the same chromosomal bands as the $\mathrm{t}(14 ; 18)(\mathrm{q} 32 ; \mathrm{q} 21) / I G H-B C L 2$ found in follicular lymphoma, it is clearly distinct. ${ }^{65}{ }^{66}$ The $\mathrm{t}(14 ; 18)(\mathrm{q} 32 ; \mathrm{q} 21) / I G H-M A L T 1$ is found most often in MALT lymphomas arising at non-gastric sites, being identified in 5-25\% of cases arising in the ocular adnexa, lung, salivary gland and skin. ${ }^{5367}$ The $\mathrm{t}(14 ; 18)(\mathrm{q} 32 ; \mathrm{q} 21) / I G H$ MALT1 can be readily detected by interphase FISH using either in-house or commercially available probes.

\section{$\dagger(1 ; 14)(p 22 ; q 32) / I G H-B C L 10$}

A small minority of MALT lymphomas contain a $\mathrm{t}(\mathrm{l} ; 14)(\mathrm{p} 22 ; \mathrm{q} 32) /$ $I G H-B C L 10$, or rarely a variant $\mathrm{t}(1 ; 2)(\mathrm{p} 22 ; \mathrm{p} 12)$ involving the $I G K$ gene locus, often together with aneuploidy. ${ }^{68}{ }^{69}$ Approximately $4 \%$ of gastric and up to $8 \%$ of pulmonary MALT lymphomas carry a $\mathrm{t}(1 ; 14)(\mathrm{p} 22 ; \mathrm{q} 32)$, and very occasional cases at other sites may do so, ${ }^{5367}$ but this translocation has not been identified in other lymphoma types. The $\mathrm{t}(1 ; 14)(\mathrm{p} 22 ; \mathrm{q} 32)$ and $\mathrm{t}(1 ; 2)(\mathrm{p} 22 ; \mathrm{p} 12)$ can be reliably detected by interphase FISH. All cases harbouring these translocations show strong aberrant nuclear Bcllo immunostaining, with much more intense and robust staining than seen in cases with a $\mathrm{t}(11 ; 18)(\mathrm{q} 21 ; \mathrm{q} 21) .{ }^{64} 67$ 


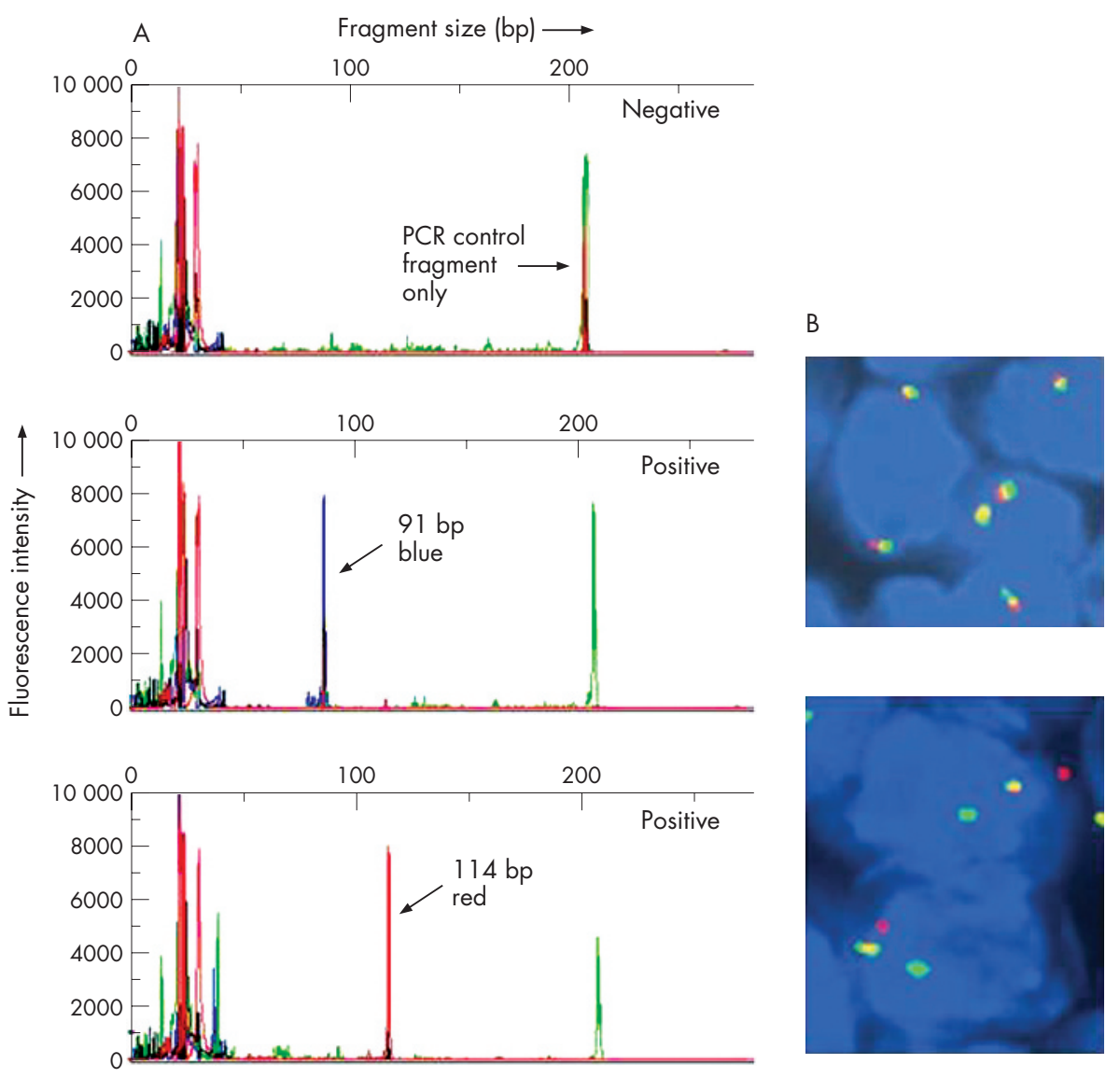

Figure 7 Detection of $\mathrm{t}(11 ; 18)(\mathrm{API} 2 / \mathrm{MALT} 1)$ in paraffin-embedded tissues. (A) Representative printouts from a reverse transcriptase-PCR method. This is a single-tube PCR using primer sets designed to detect all eight reported fusion transcripts and a PCR control fragment in mRNA from paraffin-embedded tissues. One primer in each pair has a coloured fluorescent tag, the fragments are detected by capillary electrophoresis and the transcripts are identified by the size and colour of the amplified fragments (test developed by Dr R McClure, Mayo Clinic, Rochester, Minnesota, USA). (B) Figure showing results of fluorescence in situ hybridisation using a mucosa-associated lymphoid tissue (MALT) 1 break-apart probe on paraffin sections of gastric MALT lymphoma with (lower panel) or without (upper panel) $t(11 ; 18)$ (API2/MALT1). In the upper panel, two fusion signals are detected in each nucleus (normal pattern). In the lower panel, nuclei show one fusion signal, one green signal and one red signal indicating a chromosomal break at the MALT1 gene locus.

\section{$\dagger(3 ; 14)(\mathrm{p} 14 ; \mathrm{q} 32) / / G H-F O X P 1$}

The most recently described recurrent translocation in MALT lymphoma is the $\mathrm{t}(3 ; 14)(\mathrm{pl} 4 ; \mathrm{q} 32) / I G H-F O X P 1$, which results in the overexpression of forkhead box (FOX)Pl mRNA and protein. ${ }^{70}{ }^{71}$ The functions of the transcription factor FOXPl and the mechanisms by which it promotes lymphomagenesis are unknown. The first study to report the $t(3 ; 14)(\mathrm{pl} ; 4 ; 32)$ in MALT lymphoma demonstrated its presence in $10 \%$ of the cases studied, including three of six cases from the thyroid gland, four of 20 ocular adnexal MALT lymphomas and two of 20 cutaneous cases. ${ }^{70}$ The $\mathrm{t}(3 ; 14)(\mathrm{pl} 4 ; \mathrm{q} 32)$ was typically seen together with additional genetic abnormalities. None of the gastric, salivary gland and pulmonary MALT lymphomas studied carried the translocation. However, other groups have subsequently reported FOXPI translocations to be present very rarely ( $1 \%$ of cases) or not at all in large series of MALT lymphomas. ${ }^{71-73}$ Moreover, recent studies have shown that translocations involving FOXP1 also occur in a small proportion of diffuse large B cell lymphomas and perhaps other B cell lymphomas, often with extranodal presentation. ${ }^{73}{ }^{74}$ Some of these translocations involve partner genes other than $I G H$. Thus, the precise relationship between FOXPI translocations and MALT lymphoma remains to be clarified, and the clinical significance of the detection of such translocations is unclear.

\section{PROGNOSTIC FACTORS}

Most evidence concerning the treatment and prognostic evaluation of MALT lymphomas has, not surprisingly, been accrued for gastric MALT lymphomas. In keeping with the critical pathogenetic role of $H$ pylori, it is now well established that approximately $75 \%$ of patients with a gastric MALT lymphoma achieve a durable remission after antibiotic-induced eradication of the bacterium, ${ }^{20} 7576$ and that $H$ pylori eradication treatment is the initial treatment of choice in the majority of patients with localised disease. ${ }^{77}$ In those patients with advanced-stage, $H$ pylori-negative or antibiotic-resistant gastric MALT lymphoma, and in those with primary non-gastric disease, radiotherapy, chemotherapy or rituximab may be used, although consensus guidelines for the management of such patients are not established. The provision of prognostic information, and particularly the identification of those patients with gastric MALT lymphomas unlikely to respond to $H$ pylori eradication treatment, is an important part of the diagnostic examination of a MALT lymphoma, in which the pathologist has a major role.

\section{Staging}

Although there is no generally agreed staging protocol or classification scheme for gastric MALT lymphoma (eg, some 


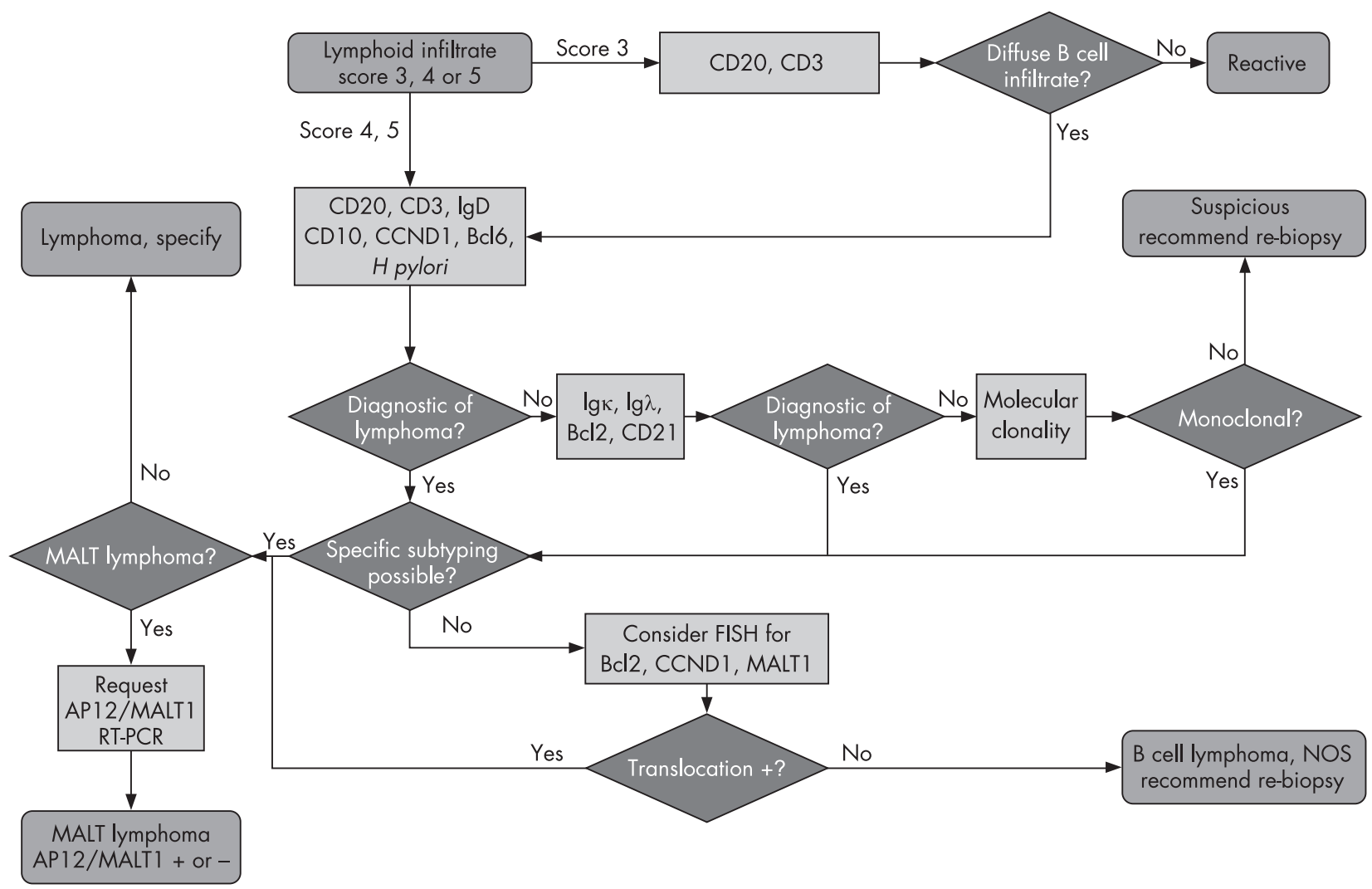

Figure 8 An algorithm for the diagnostic examination of gastric mucosa-associated lymphoid tissue (MALT) lymphoma (modified from Mayo Clinic, Lymph Node Working Group clinical practice guidelines). FISH, fluorescence in situ hybridisation.

groups use an adapted version of Musshoff's modified Ann Arbor staging system, $^{78}$ whereas others use the Lugano modification of the Blackledge staging scheme ${ }^{79}$ ), some important principles have emerged. The appreciation that the locoregional staging of gastric MALT lymphoma using endoscopic ultrasonography is prognostically valuable is most notable. Using this methodology, several studies have shown that increasing depth of invasion of lymphoma through the stomach wall is closely correlated with decreasing responsiveness to $H$ pylori eradication treatment. ${ }^{80-83}$ Similar studies have also shown that involvement of the regional lymph nodes (which occurs in approximately $15-30 \%$ of gastric MALT lymphomas) is associated with considerably reduced response rates to either antibiotics or conventional treatment. ${ }^{83-85}$ Thus, gastric MALT lymphomas of stage 2E or above (Musshoff's modified Ann Arbor staging system) are unlikely to respond to $H$ pylori eradication, whereas those with stage $\mathrm{lE}_{1}$ disease, and particularly those with disease confined to the mucosa, do so in approximately $80 \%$ of cases.

MALT lymphomas remain localised (stage 1 or 2 ) in the majority of cases. However, recent studies using comprehensive staging protocols have shown that $25-35 \%$ of MALT lymphomas, more frequently among non-gastric than gastric cases, present with disseminated disease. ${ }^{86-89}$ In many of these cases, characteristic involvement of multiple mucosal sites is seen, leading some to suggest that thorough examination and imaging of all MALT sites should be part of the routine staging investigations for patients with MALT lymphoma. ${ }^{89}$ The bone marrow is involved in this lymphoma in up to $15 \%$ of cases, although fewer gastric lymphomas than this spread to the marrow, and more pulmonary cases do $50 .{ }^{86}{ }^{90} 91$ Less than $10 \%$ of patients have distant lymph node involvement. ${ }^{86} 8992$

\section{Histopathology of lymph node and bone marrow spread}

In the typical pattern of nodal involvement, centrocyte-like or monocytoid cells surround reactive follicles in a marginal zone distribution. With more extensive involvement, the infiltrate coalesces to form confluent sheets which eventually efface the entire node. Involvement of the spleen produces a similar appearance. MALT lymphoma in the bone marrow most often shows a mixed pattern of randomly distributed aggregates of marginal zone cells with an associated interstitial infiltrate. ${ }^{93}$

\section{Prognostic implications of histological features}

Several early studies on gastric lymphoma showed that the presence of DLBCL, either with or without a "low grade" MALT lymphoma component, was associated with more advanced disease and a worse outcome than for typical MALT lymphoma alone after conventional treatment. ${ }^{7849495}$ In one study of gastric MALT lymphoma treated by H pylori eradication, among six patients who failed to respond, subsequent gastrectomy revealed previously unrecognised DLBCL in three. ${ }^{96}$ In another study, patients with MALT lymphoma and DLBCL had worse event-free survival than patients with MALT lymphoma alone, suggesting that DLBCL may be relatively resistant to antibiotic treatment. ${ }^{97}$ Interestingly however, several reports have now shown that some early-stage gastric DLBCL, with or without associated MALT lymphoma, do respond to antibiotics. ${ }^{809698}$ Nevertheless, the role of antibiotics in treating such lymphomas requires clarification, and, as the presence of DLBCL is usually considered to be an indication for cytotoxic treatment, ${ }^{90}$ it is important to correctly identify and classify those cases in which DLBCL is present. 
Table 2 Groupe d'Etude des Lymphomes de l'Adulte histological grading system for posttreatment evaluation of gastric mucosa-associated lymphoid tissue lymphoma ${ }^{115}$

\begin{tabular}{llll} 
Score & Lymphoid infiltrate & LEL & Stromal changes \\
\hline CR & $\begin{array}{l}\text { Absent or scattered plasma cells and small lymphoid cells in }- \\
\text { the LP }\end{array}$ & $\begin{array}{l}\text { Normal or empty LP and/or } \\
\text { fibrosis }\end{array}$ \\
pMRD & $\begin{array}{l}\text { Aggregates of lymphoid cells or lymphoid nodules in the } \\
\text { LP/MM and/or SM }\end{array}$ & Empty LP and/or fibrosis \\
rRD & $\begin{array}{l}\text { Dense, diffuse or nodular extension around glands in the LP } \\
\text { NC }\end{array}$ & Dense, diffuse or nodular & $\begin{array}{l}\text { Focal empty LP and/or fibrosis } \\
\text { No changes }\end{array}$ \\
\hline
\end{tabular}

CR, complete histological remission; LEL, lymphoepithelial lesions; LP, lamina propria; MM, muscularis mucosa; NC, no change; $\mathrm{pMRD}$, probable minimal residual disease; rRD, responding residual disease; $S M$, submucosa.

The prognostic significance of the number of dispersed large transformed B cells in MALT lymphomas without overt DLBCL is a matter of uncertainty. Some studies reported that gastric MALT lymphomas containing $>1 \%^{94} 99$ or $>5 \%{ }^{100}$ diffusely intermingled large blasts, but no overt DLBCL, showed a worse outcome after radiotherapy with or without chemotherapy and/ or responded less often to $H$ pylori eradication treatment. However, other studies have failed to find similar prognostic effects in either gastric ${ }^{85}{ }^{101}$ or non-gastric cases. ${ }^{88}$ At present, there are no established guidelines for the "grading" of MALT lymphoma in this manner.

As discussed above, the pathologist may also contribute to prognostication by reporting the absence of $H$ pylori, as $H$ pylorinegative cases are less likely to respond to antibiotic treatment. ${ }^{8283102}$ A single study has reported that the immunohistochemical detection of nuclear staining for either Bcllo or $\mathrm{NF \kappa B}$ is associated with the resistance of gastric MALT lymphomas to antibiotic treatment. ${ }^{103}$ However, the poor reproducibility of such staining (with the possible exception of the strong nuclear Bcllo staining associated with $\mathrm{t}(1 ; 14)(\mathrm{p} 22 ; \mathrm{q} 32))$ is likely to limit the clinical application of this approach. Finally, a recent study has reported that strong expression of FoxPl protein in MALT lymphoma is associated with polymorphic cellular morphology, trisomy $3 / 18$ and an adverse prognosis associated with transformation to DLBCL ${ }^{104}$; however, the utility of immunostaining for FoxPl in MALT lymphomas remains to be confirmed.

\section{Prognostic implications of molecular genetic changes}

Several studies have addressed the prognostic implications of genetic changes in MALT lymphoma. Most importantly, Liu et al have firmly established that the presence of $\mathrm{t}(11 ; 18)(\mathrm{q} 21 ; \mathrm{q} 21)$ is strongly associated with the failure of gastric MALT lymphoma at all stages to regress after $H$ pylori eradication treatment. ${ }^{61}{ }^{105}$ The presence of this translocation may, at least in part, explain the failure of $20 \%$ of early-stage gastric MALT lymphomas to respond to such treatment. Further studies have suggested that, compared with $\mathrm{t}(11 ; 18)(\mathrm{q} 21 ; \mathrm{q} 21)$-negative cases, $\mathrm{t}(11 ; 18)(\mathrm{q} 21 ; \mathrm{q} 21)$-positive cases also show a worse response to treatment with oral alkylating agents, ${ }^{106}$ but not to rituximab ${ }^{107}$ or cladribine. ${ }^{108}$ Moreover, $\mathrm{t}(11 ; 18)(\mathrm{q} 21 ; \mathrm{q} 21)$ is found much more frequently in those cases that have spread beyond the stomach than in those confined to the gastric wall, ${ }^{57}$ and is found more frequently in $H$ pylori-negative patients than in those with the bacterium. ${ }^{102}$ Finally, the observation that a $\mathrm{t}(11 ; 18)(\mathrm{q} 21 ; \mathrm{q} 21)$ is rarely found in extranodal DLBCL, with or without a MALT lymphoma component, suggests that MALT lymphomas containing the translocation are less likely than aneuploid $t(11 ; 18)(\mathrm{q} 21 ; \mathrm{q} 21)$ negative cases to transform to DLBCL. ${ }^{60}{ }^{109}$ Determination of the $\mathrm{t}(11 ; 18)(\mathrm{q} 21 ; \mathrm{q} 21)$ status of a gastric MALT lymphoma by FISH or reverse transcriptase-PCR is thus of critical importance in clinical decision making (fig 7). Experience with a small number of cases suggests that the presence of a BCL10 translocation in gastric MALT lymphoma may also be associated with advanced-stage disease. ${ }^{110}$ The significance of genetic changes to prognosis in non-gastric MALT lymphomas is largely unknown.

\section{OUTCOME AND POST-TREATMENT ASSESSMENT OF MALT LYMPHOMA}

The overall survival of patients with MALT lymphoma is approximately $85-95 \%$ at 5 years, probably with little difference between sites. ${ }^{86} 8890$ Approximately $25-35 \%$ of patients from all sites relapse after a complete response, often late and to a further mucosal site, although significantly more non-gastric $(25-40 \%)$ than gastric $(5-20 \%)$ cases do so. $^{87111-113}$ Late transformation occurs in $<10 \%$ of cases. ${ }^{113}$

\section{Post-treatment biopsies of gastric MALT lymphoma}

Serial gastroscopy with histological assessment of multiple biopsies (and endoscopic ultrasonography, if this was abnormal at diagnosis) is the best method of post-treatment follow-up currently available for gastric MALT lymphoma. ${ }^{114}$ Although there is no widely agreed protocol, biopsies are typically taken every 3-6 months for the first 2 years, and yearly thereafter. ${ }^{77} \mathrm{~A}$ good histological response of gastric MALT lymphoma to antibiotic treatment is characterised by regression of the diffuse lymphoid infiltrate and lymphoepithelial lesions seen at diagnosis, although basal aggregates of morphologically nonsuspicious B and T cells, sometimes associated with FDC, often remain. The lamina propria appears empty or fibrotic, with gland loss and scattered lymphocytes and plasma cells. ${ }^{42} 115$ To facilitate effective communication between pathologists and physicians, a reproducible and simple histological grading system for post-treatment evaluation of gastric MALT lymphoma has been devised recently ${ }^{115}$ (table 2). It is important to appreciate that the presence of basal lymphoid aggregates without other features of lymphoma is not associated with active disease, and that the Groupe d'Etude des Lymphomes de l'Adulte category "probable minimal residual disease (pMRD)" is not at present an indication for further treatment, and can be managed as a state of remission with appropriate follow-up.

Although most patients who achieve a complete response/ pMRD remain in stable remission, approximately $5-15 \%$ relapse within the stomach. ${ }^{9711112}$ In some cases, relapse is associated with reinfection by $H$ pylori, and further antibiotic treatment usually results in a further remission. ${ }^{76} 116117$ For this reason, and because failure to eradicate $H$ pylori is associated with failure to enter remission after the first treatment, ${ }^{98}$ the pathologist should assess the presence or absence of $H$ pylori in all follow-up biopsies. In some cases, often not associated with re-infection, apparent relapses are transient and selflimiting (although whether these truly represent relapses rather than persistent residual disease remains uncertain)..$^{9711}$ Thus, repeated and multiple biopsies may be necessary to establish a state of remission or relapse, particularly given the possible confounding effects of sampling variation between biopsies. It 
is undefined how long to observe those who fail, or are slow, to respond before instituting second-line therapy, particularly since many patients who show only a partial response 1 year after treatment seem to follow a favourable course, often achieving remission. ${ }^{118}$

\section{Significance of B cell clonality in post-treatment gastric biopsies}

Several studies have investigated the role of assessing B cell clonality in gastric biopsies after antibiotic treatment for MALT lymphoma. In approximately $50 \%$ of cases, B cell monoclonality persists after the attainment of complete response/pMRD status, although in at least some of these patients the clonal population gradually disappears with time. ${ }^{76}{ }^{119}$ In many such cases, the monoclonal population appears to be located within basal aggregates of dormant disease. Continued monoclonality after eradication of $\mathrm{H}$ pylori may be associated with a delay in achieving remission. ${ }^{120}$ In some studies, patients in remission but with persistent monoclonality in follow-up biopsies were significantly more likely to relapse than those whose biopsies were persistently polyclonal. ${ }^{111}{ }^{119}$ However, sampling error seriously confounds these studies, and whether these patients were ever truly in remission is unclear. Moreover, other similar studies have shown no association between monoclonality and the risk of relapse. ${ }^{38} 76121$ The difficulty in interpreting such clonality data is compounded by the fact that assessment of serial biopsies from many patients shows fluctuating clonal status, possibly as a result of sampling issues or even reinfection by $H$ pylori. Thus, although further studies are required, current evidence does not support a role for assessment of clonality in post-treatment follow-up of gastric MALT lymphomas beyond the research setting.

\section{Gastric adenocarcinoma after gastric MALT lymphoma}

A final aspect of the follow-up of gastric MALT lymphoma is the importance of surveillance for gastric adenocarcinoma. Numerous papers describe the synchronous occurrence of these two conditions, ${ }^{122}{ }^{123}$ possibly as a result of the major pathogenic role of $H$ pylori in both diseases. Moreover, several reports have also described the occurrence of early gastric cancer following apparent complete remission of MALT lymphoma after $H$ pylori eradication or oral chemotherapy. ${ }^{124-126}$ Although the precise relationship between gastric MALT lymphoma and metachronous carcinoma remains unclear, these reports underline the importance of long-term endoscopic follow-up of gastric MALT lymphoma and suggest that the pathologist should be mindful of the possibility of finding dysplasia or adenocarcinoma in these biopsies.

\section{AN INTEGRATED DIAGNOSTIC APPROACH}

From the above discussion, it is clear that optimal diagnosis and management of a MALT lymphoma by a surgical pathologist requires careful integration of morphological, immunohistochemical and molecular information, together with close cooperation with clinical colleagues. Figure 8 presents, in an algorithmic form, one integrated approach to the management of gastric lymphoid infiltrates suspicious for MALT lymphoma. A similar approach could readily be adopted for the assessment of suspected MALT lymphomas at other sites. The diagnosis of a gastric MALT lymphoma should prompt molecular testing for $\mathrm{t}(11 ; 18)(\mathrm{q} 21 ; \mathrm{q} 21) / A P I 2-M A L T 1$ and staining for $H$ pylori to further inform clinical management. In view of the clinical implications of identifying coexistent DLBCL in a MALT lymphoma, some teams recommend a further endoscopy, with multiple biopsy specimens taken from the affected area using large-calibre forceps, in order to identify or exclude transformed disease. ${ }^{114}$ This could be combined with endoscopic ultrasonography to provide detailed staging information.

\section{ACKNOWLEDGEMENTS}

CMB is supported by a Senior Clinician Scientist Fellowship from The Health Foundation, The Royal College of Pathologists, and The Pathological Society of Great Britain and Ireland. M-QD is supported by the Leukaemia Research Fund. AD is supported by the NIH, University of Iowa/Mayo Clinic Lymphoma SPORE grant (P50 CA097274).

\section{Authors' affiliations}

Chris M Bacon, Ming-Qing Du, Department of Pathology, University of Cambridge, Cambridge, UK

Ahmet Dogan, Department of Laboratory Medicine and Pathology, Mayo Clinic, Rochester, Minnesota, USA

Competing interests: None declared.

\section{REFERENCES}

1 The Non-Hodgkin's Lymphoma Classification Project. A clinical evaluation of the International Lymphoma Study Group classification of non-Hodgkin's lymphoma. Blood 1997;89:3909-18.

2 Isaacson PG, Du MQ. MALT lymphoma: from morphology to molecules. Nat Rev Cancer 2004;4:644-53.

3 Wotherspoon AC, Ortiz-Hidalgo C, Falzon MR, et al. Helicobacter pyloriassociated gastritis and primary B-cell gastric lymphoma. Lancet 1991;338:1175-6.

4 Parsonnet J, Hansen S, Rodriguez L, et al. Helicobacter pylori infection and gastric lymphoma. N Engl J Med 1994;330:1267-71.

5 Hussell T, Isaacson PG, Crabtree JE, et al. The response of cells from low-grade B-cell gastric lymphomas of mucosa-associated lymphoid tissue to Helicobacter pylori. Lancet 1993;342:571-4.

6 Hussell T, Isaacson PG, Spencer J. Proliferation and differentiation of tumour cells from B-cell lymphoma of mucosa-associated lymphoid tissue in vitro. J Pathol 1993;169:221-7.

7 Ferreri AJ, Guidoboni M, Ponzoni M, et al. Evidence for an association between Chlamydia psittaci and ocular adnexal lymphomas. J Natl Cancer Inst 2004:96:586-94.

8 Ambrosetti A, Zanotti R, Pattaro C, et al. Most cases of primary salivary mucosa-associated lymphoid tissue lymphoma are associated either with Sjögren syndrome or hepatitis C virus infection. Br J Haematol 2004; 126:43-9.

9 Lecuit M, Abachin E, Martin A, et al. Immunoproliferative small intestinal disease associated with Campylobacter jejuni. N Engl J Med 2004;350:239-48.

10 Ferreri AJ, Ponzoni M, Guidoboni M, et al. Regression of ocular adnexal lymphoma after Chlamydia psittaci-eradicating antibiotic therapy. J Clin Oncol 2005;23:5067-73.

11 Chanudet E, Zhou Y, Bacon C, et al. Chlamydia psittaci is variably associated with ocular adnexal MALT lymphoma in different geographical regions. J Patho 2006;209:344-51.

12 Rosado MF, Byrne GE Jr, Ding F, et al. Ocular adnexal lymphoma: a clinicopathologic study of a large cohort of patients with no evidence for an association with Chlamydia psittaci. Blood 2006;107:467-72.

13 Ashton-Key M, Diss TC, Isaacson PG. Detection of Helicobacter pylori in gastric biopsy and resection specimens. J Clin Pathol 1996;49:107-11.

14 Isaacson PG, Norton AJ. Extranodal lymphomas. Edinburgh: Churchill Livingstone, 1994.

15 Isaacson PG, Muller Hermelink HK, Piris MA, et al. Extranodal marginal zone lymphoma of muocsa-associated lymphoid tissue (MALT lymphoma). In: Jaffe ES, Harris NL, Stein H, Vardiman JW, eds. World Health Organisation Classification of Tumours. Pathology and genetics of tumours of haematopoietic and lymphoid tissues. Lyon: IARC Press, 2001:157-60.

16 Isaacson PG, Spencer J. Malignant lymphoma of mucosa-associated lymphoid tissue. Histopathology 1987;11:445-62.

17 Ferry JA, Yang WI, Zukerberg LR, et al. CD5+ extranodal marginal zone B-cell (MALT) lymphoma. A low grade neoplasm with a propensity for bone marrow involvement and relapse. Am J Clin Pathol 1996;105:31-7.

18 Ballesteros E, Osborne BM, Matsushima AY. CD5+ low-grade marginal zone Bcell lymphomas with localized presentation. Am J Surg Pathol 1998;22:201-7.

19 Zukerberg LR, Ferry JA, Southern JF, et al. Lymphoid infiltrates of the stomach. Evaluation of histologic criteria for the diagnosis of low-grade gastric lymphoma on endoscopic biopsy specimens. Am J Surg Pathol 1990;14:1087-99.

20 Wotherspoon AC, Doglioni C, Diss TC, et al. Regression of primary low-grade B-cell gastric lymphoma of mucosa-associated lymphoid tissue type after eradication of Helicobacter pylori. Lancet 1993;342:575-7.

21 Kurtin PJ, Myers JL, Adlakha H, et al. Pathologic and clinical features of primary pulmonary extranodal marginal zone B-cell lymphoma of MALT type. Am J Surg Pathol 2001;25:997-1008.

22 Fiche M, Caprons F, Berger F, et al. Primary pulmonary non-Hodgkin's lymphomas. Histopathology 1995;26:529-37. 
$23 \operatorname{Lim} \mathrm{JK}$, Lacy MQ, Kurtin PJ, et al. Pulmonary marginal zone lymphoma of MALT type as a cause of localised pulmonary amyloidosis. J Clin Pathol 2001;54:642-6.

24 Hyjek E, Smith WJ, Isaacson PG. Primary B-cell lymphoma of salivary glands and its relationship to myoepithelial sialadenitis. Hum Pathol 1988;19:766-76.

25 Diss TC, Wotherspoon AC, Speight P, et al. B-cell monoclonality, Epstein Barr virus, and $t(14 ; 18)$ in myoepithelial sialadenitis and low-grade B-cell MALT lymphoma of the parotid gland. Am J Surg Pathol 1995;19:531-6.

26 Quintana PG, Kapadia SB, Bahler DW, et al. Salivary gland lymphoid infiltrates associated with lymphoepithelial lesions: a clinicopathologic, immunophenotypic, and genotypic study. Hum Pathol 1997;28:850-61.

27 Coupland SE, Krause L, Delecluse HJ, et al. Lymphoproliferative lesions of the ocular adnexa. Analysis of 112 cases. Ophthalmology 1998;105:1430-41.

28 Willemze R, Jaffe ES, Burg G, et al. WHO-EORTC classification for cutaneous lymphomas. Blood 2005; 105:3768-85.

29 Hyjek E, Isaacson PG. Primary B cell lymphoma of the thyroid and its relationship to Hashimoto's thyroiditis. Hum Pathol 1988;19:1315-26.

30 Derringer GA, Thompson LD, Frommelt RA, et al. Malignant lymphoma of the thyroid gland: a clinicopathologic study of 108 cases. Am J Surg Pathol 2000;24:623-39.

31 Chan JK, Ng CS, Isaacson PG. Relationship between high-grade lymphoma and low-grade B-cell mucosa-associated lymphoid tissue lymphoma (MALToma) of the stomach. Am J Pathol 1990;136:1153-64.

32 Isaacson PG, Wotherspoon AC, Diss T, et al. Follicular colonization in B-cell lymphoma of mucosa-associated lymphoid tissue. Am J Surg Pathol 1991;15:819-28.

33 Isaacson PG, Androulakis-Papachristou A, Diss TC, et al. Follicular colonization in thyroid lymphoma. Am J Pathol 1992;141:43-52.

34 Isaacson PG, Wotherspoon AC, Diss TC, et al. Bcl-2 expression in lymphomas. Lancet 1991;337:175-6.

35 Spagnolo DV, Ellis DW, Juneja S, et al. The role of molecular studies in lymphoma diagnosis: a review. Pathology 2004;36:19-44.

36 van Dongen JJ, Langerak AW, Bruggemann $M$, et al. Design and standardization of PCR primers and protocols for detection of clonal immunoglobulin and T-cell receptor gene recombinations in suspect lymphoproliferations: report of the BIOMED-2 Concerted Action BMH4-CT983936. Leukemia 2003;17:2257-317.

37 McClure RF, Kaur P, Pagel E, et al. Validation of immunoglobulin gene rearrangement detection by PCR using commercially available BIOMED-2 primers. Leukemia 2006;20:176-9.

38 Bertoni F, Conconi A, Capella C, et al. Molecular follow-up in gastric mucosaassociated lymphoid tissue lymphomas: early analysis of the LYO3 cooperative trial. Blood 2002;99:2541-4.

39 Hummel M, Oeschger S, Barth TF, et al. Wotherspoon criteria combined with Bcell clonality analysis by advanced PCR technology discriminates cryptic gastric marginal zone lymphoma from chronic gastritis. Gut 2006;55:782-7.

40 Aiello A, Giardini R, Tondini C, et al. PCR-based clonality analysis: a reliable method for the diagnosis and follow-up monitoring of conservatively treated gastric B-cell MALT lymphomas? Histopathology 1999;34:326-30.

41 de Mascarel A, Dubus P, Belleannee G, et al. Low prevalence of monoclonal B cells in Helicobacter pylori gastritis patients with duodenal ulcer. Hum Pathol 1998;29:784-90.

42 Savio A, Franzin G, Wotherspoon AC, et al. Diagnosis and posttreatment follow-up of Helicobacter pylori-positive gastric lymphoma of mucosaassociated lymphoid tissue: histology, polymerase chain reaction, or both? Blood 1996;87: 1255-60.

43 Wundisch T, Neubauer A, Stolte M, et al. B-cell monoclonality is associated with lymphoid follicles in gastritis. Am J Surg Pathol 2003;27:882-7.

44 Hsi ED, Siddiqui J, Schnitzer B, et al. Analysis of immunoglobulin heavy chain gene rearrangement in myoepithelial sialadenitis by polymerase chain reaction. Am J Clin Pathol 1996;106:498-503.

45 Masaki Y, Sugai S. Lymphoproliferative disorders in Sjögren's syndrome. Autoimmun Rev 2004;3:175-82.

46 Thome M. CARMA1, BCL-10 and MALT1 in lymphocyte development and activation. Nat Rev Immunol 2004;4:348-59.

47 Lin X, Wang D. The roles of CARMA1, Bcl10, and MALT1 in antigen receptor signaling. Semin Immunol 2004;16:429-35.

48 Dierlamm J, Baens M, Wlodarska I, et al. The apoptosis inhibitor gene API2 and a novel $18 \mathrm{q}$ gene, $M L T$, are recurrently rearranged in the

$t(11 ; 18)(q 21 ; q 21) p 6 s s o c i a t e d$ with mucosa-associated lymphoid tissue lymphomas. Blood 1999;93:3601-9.

49 Akagi T, Motegi M, Tamura A, et al. A novel gene, MALT1 at 18q21, is involved in $\mathrm{t}(11 ; 18)$ (q21;q21) found in low-grade B-cell lymphoma of mucosaassociated lymphoid tissue. Oncogene 1999;18:5785-94.

50 Morgan JA, Yin Y, Borowsky AD, et al. Breakpoints of the $t(11 ; 18)(q 21 ; q 21)$ in mucosa-associated lymphoid tissue (MALT) lymphoma lie within or near the previously undescribed gene MALT1 in chromosome 18. Cancer Res 1999:59:6205-13.

51 Lucas PC, Yonezumi M, Inohara N, et al. Bcl10 and MALT1, independent targets of chromosomal translocation in malt lymphoma, cooperate in a novel NF-kappa B signaling pathway. J Biol Chem 2001;276:19012-19.

$52 \mathrm{Ye} \mathrm{H}$, Liu $\mathrm{H}$, Attygalle $A$, et al. Variable frequencies of $t(11 ; 18)(q 21 ; q 21)$ in MALT lymphomas of different sites: significant association with CagA strains of $\mathrm{H}$ pylori in gastric MALT lymphoma. Blood 2003;102:1012-18.

53 Streubel B, Simonitsch-Klupp I, Mullauer L, et al. Variable frequencies of MALT lymphoma-associated genetic aberrations in MALT lymphomas of different sites. Leukemia 2004;18:1722-6.
54 Remstein ED, James CD, Kurtin PJ. Incidence and subtype specificity of API2MALT1 fusion translocations in extranodal, nodal, and splenic marginal zone lymphomas. Am J Pathol 2000;156:1183-8.

55 Rosenwald A, OH G, Stilgenbauer S, et al. Exclusive detection of the $t(11 ; 18)(q 21 ; q 21)$ in extranodal marginal zone B cell lymphomas (MZBL) of MALT type in contrast to other MZBL and extranodal large B cell lymphomas. Am J Pathol 1999; 155:1817-21

56 Takada S, Yoshino T, Taniwaki M, et al. Involvement of the chromosomal translocation $\mathrm{t}(11 ; 18)$ in some mucosa-associated lymphoid tissue lymphomas and diffuse large B-cell lymphomas of the ocular adnexa: evidence from multiplex reverse transcriptase-polymerase chain reaction and fluorescence in situ hybridization on using formalin-fixed, paraffin-embedded specimens. Mod Pathol 2003; 16:445-52.

57 Liu $\mathrm{H}, \mathrm{Ye} \mathrm{H}$, Dogan A, et al. $\mathrm{T}(11 ; 18)(q 21 ; \mathrm{q} 21)$ is associated with advanced mucosa-associated lymphoid tissue lymphoma that expresses nuclear BCL10. Blood 2001;98:1182-7.

58 Auer IA, Gascoyne RD, Connors JM, et al. $t(11 ; 18)(q 21 ; q 21)$ is the most common translocation in MALT lymphomas. Ann Oncol 1997;8:979-85.

59 Remstein ED, Kurtin PJ, James CD, et al. Mucosa-associated lymphoid tissue lymphomas with $t(11 ; 18)(q 21 ; q 21)$ and mucosa-associated lymphoid tissue lymphomas with aneuploidy develop along different pathogenetic pathways. Am J Pathol 2002;161:63-71.

60 Starostik P, Patzner J, Greiner A, et al. Gastric marginal zone B-cell lymphomas of MALT type develop along 2 distinct pathogenetic pathways. Blood 2002;99:3-9.

61 Liu $\mathrm{H}$, Ye H, Ruskone-Fourmestraux $A$, et al. $T(11 ; 18)$ is a marker for all stage gastric MALT lymphomas that will not respond to $\mathrm{H}$. pylori eradication. Gastroenterology 2002; 122:1286-94.

62 Dierlamm J, Baens M, Stefanova-Ouzounova M, et al. Detection of $t(11 ; 18)(q 21 ; q 21)$ by interphase fluorescence in situ hybridization using API2 and MLT specific probes. Blood 2000;96:2215-18.

63 Maes B, Demunter A, Peeters B, et al. BCL10 mutation does not represent an important pathogenic mechanism in gastric MALT-type lymphoma, and the presence of the API2-MLT fusion is associated with aberrant nuclear BCL10 expression. Blood 2002;99:1398-404.

$64 \mathrm{Ye} \mathrm{H}$, Dogan A, Karran L, et al. BCL10 expression in normal and neoplastic lymphoid tissue. Nuclear localization in MALT lymphoma. Am J Pathol 2000; 157:1147-54

65 Streubel B, Lamprecht A, Dierlamm J, et al. T(14;18)(q32;q21) involving IGH and MALT1 is a frequent chromosomal aberration in MALT lymphoma. Blood 2003;101:2335-9.

66 Sanchez-Izquierdo D, Buchonnet G, Siebert R, et al. MALT1 is deregulated by both chromosomal translocation and amplification in B-cell non-Hodgkin lymphoma. Blood 2003;101:4539-46.

67 Ye H, Gong L, Liu H, et al. MALT lymphoma with $\mathrm{t}(14 ; 18)(\mathrm{q} 32 ; \mathrm{q} 21) / \mathrm{IGH}$ MALT1 is characterized by strong cytoplasmic MALT1 and BCL10 expression. J Pathol 2005:205:293-301.

68 Zhang $Q$, Siebert R, Yan $M$, et al. Inactivating mutations and overexpression of $B C L 10$, a caspase recruitment domain-containing gene, in MALT lymphoma with $t(1 ; 14)(p 22 ; q 32)$. Nat Genet 1999;22:63-8.

69 Willis TG, Jadayel DM, Du MQ, et al. Bcl10 is involved in $+(1 ; 14)(p 22 ; q 32)$ of MALT B cell lymphoma and mutated in multiple tumor types. Cell 1999;96:35-45.

70 Streubel B, Vinatzer U, Lamprecht A, et al. T(3;14)(p14.1;q32) involving IGH and FOXP1 is a novel recurrent chromosomal aberration in MALT lymphoma. Leukemia 2005;19:652-8.

71 Wlodarska I, Veyt E, De Paepe $P$, et al. FOXP1, a gene highly expressed in a subset of diffuse large B-cell lymphoma, is recurrently targeted by genomic aberrations. Leukemia 2005; 19:1299-305.

72 Remstein ED, Dogan A, Einerson RR, et al. The incidence and anatomic site specificity of chromosomal translocations in primary extranodal marginal zone B-cell lymphoma of mucosa-associated lymphoid tissue (MALT lymphoma) in North America. Am J Surg Pathol 2006;30:1546-53.

73 Haralambieva E, Adam P, Ventura R, et al. Genetic rearrangement of FOXP1 is predominantly detected in a subset of diffuse large B-cell lymphomas with extranodal presentation. Leukemia 2006;20:1300-3.

74 Fenton JA, Schuuring E, Barrans SL, et al. $t(3 ; 14)(p 14 ; q 32)$ results in aberrant expression of FOXP1 in a case of diffuse large B-cell lymphoma. Genes Chromosomes Cancer 2006:45:164-8.

75 Bayerdorffer E, Neubaver A, Rudolph B, et al. Regression of primary gastric lymphoma of mucosa-associated lymphoid tissue type after cure of Helicobacter pylori infection. MALT Lymphoma Study Group. Lancet 1995;345:1591-4.

76 Du $M Q$, Isaccson PG. Gastric MALT lymphoma: from aetiology to treatment. Lancet Oncol 2002:3:97-104.

77 Bertoni F, Zucca E. State-of-the-art therapeutics: marginal-zone lymphoma. J Clin Oncol 2005;23:6415-20.

78 Radaszkiewicz T, Dragosics B, Bauer P. Gastrointestinal malignant lymphomas of the mucosa-associated lymphoid tissue: factors relevant to prognosis. Gastroenterology 1992;102:1628-38.

79 Rohatiner A, d'Amore F, Coiffier B, et al. Report on a workshop convened to discuss the pathological and staging classifications of gastrointestinal tract lymphoma. Ann Oncol 1994;5:397-400.

80 Nakamura S, Matsumoto T, Suekane H, et al. Predictive value of endoscopic ultrasonography for regression of gastric low grade and high grade MALT lymphomas after eradication of Helicobacter pylori. Gut 2001;48:454-60.

81 Sackmann M, Morgner A, Rudolph B, et al. Regression of gastric MALT lymphoma after eradication of Helicobacter pylori is predicted by endosonographic staging. MALT Lymphoma Study Group. Gastroenterology $1997 ; 113: 1087-90$ 
82 Steinbach G, Ford R, Glober G et al. Antibiotic treatment of gastric lymphoma of mucosa-associated lymphoid tissue. An uncontrolled trial. Ann Intern Med 1999;131:88-95.

83 Ruskone-Fourmestraux A, Lavergne A, Aegerter PH, et al. Predictive factors for regression of gastric MALT lymphoma after anti-Helicobacter pylori treatment. Gut $2001 ; 48: 297-303$

84 Cogliatti SB, Schmid U, Schumacher U, et al. Primary B-cell gastric lymphoma: a clinicopathological study of 145 patients. Gastroenterology 1991;101:1159-70.

85 Levy M, Copie-Bergman C, Traulle C, et al. Conservative treatment of primary gastric low-grade B-cell lymphoma of mucosa-associated lymphoid tissue: predictive factors of response and outcome. Am J Gastroenterol 2002:97:292-7.

86 Thieblemont C, Berger F, Dumontet C, et al. Mucosa-associated lymphoid tissue lymphoma is a disseminated disease in one third of 158 patients analyzed. Blood 2000;95:802-6.

87 Zinzani PL, Magagnoli M, Galieni P, et al. Nongastrointestinal low-grade mucosa-associated lymphoid tissue lymphoma: analysis of 75 patients. J Clin Oncol 1999; 17:1254.

88 Zucca E, Conconi A, Pedrinis E, et al. Nongastric marginal zone B-cell lymphoma of mucosa-associated lymphoid tissue. Blood 2003;101:2489-95.

89 Raderer M, Vorbeck F, Formanek M et al. Importance of extensive staging in patients with mucosa-associated lymphoid tissue (MALT)-type lymphoma. Br J Cancer 2000;83:454-7.

90 Zucca E, Bertoni F, Roggero E, et al. The gastric marginal zone B-cell lymphoma of MALT type. Blood 2000;96:410-19.

91 Thieblemont $C$. Clinical presentation and management of marginal zone lymphomas. Hematology 2005 (Am Soc Hematol Educ Program) 2005:307-13.

92 Thieblemont C, Bastion Y, Berger F, et al. Mucosa-associated lymphoid tissue gastrointestinal and nongastrointestinal lymphoma behavior: analysis of 108 patients. J Clin Oncol 1997;15:1624-30.

93 Kent SA, Variakojis D, Peterson LC. Comparative study of marginal zone lymphoma involving bone marrow. Am J Clin Pathol 2002;117:698-708.

94 de Jong $D$, Boot $H$, van Heerde $P$, et al. Histological grading in gastric lymphoma: pretreatment criteria and clinical relevance. Gastroenterology 1997:112:1466-74.

95 Montalban C, Castrillo JM, Abraira V, et al. Gastric B-cell mucosa-associated lymphoid tissue (MALT) lymphoma. Clinicopathological study and evaluation of the prognostic factors in 143 patients. Ann Oncol 1995;6:355-62.

96 Morgner A, Miehlke S, Fischbach W, et al. Complete remission of primary highgrade B-cell gastric lymphoma after cure of Helicobacter pylori infection. J Clin Oncol 2001; 19:2041-8.

97 Nakamura S, Matsumoto T, Suekane H, et al. Long-term clinical outcome of Helicobacter pylori eradication for gastric mucosa-associated lymphoid tissue lymphoma with a reference to second-line treatment. Cancer 2005; 104:532-40

98 Chen LT, Lin JT, Tai JJ, et al. Long-term results of anti-Helicobacter pylori therapy in early-stage gastric high-grade transformed MALT lymphoma. J Natl Cancer Inst 2005;97:1345-53.

99 de Jong D, Vyth-Dreese F, Dellemijn T, et al. Histological and immunological parameters to predict treatment outcome of Helicobacter pylori eradication in low-grade gastric MALT lymphoma. J Pathol 2001;193:318-24.

100 Harris NL, Jaffe ES, Diebold J, et al. The World Health Organization classification of neoplastic diseases of the haematopoietic and lymphoid tissues: Report of the Clinical Advisory Committee Meeting, Airlie House, Virginia, November 1997. Histopathology 2000;36:69-86.

101 Ferreri AJ, Freschi M, Dell'Oro S, et al. Prognostic significance of the histopathologic recognition of low- and high-grade components in stage I-II Bcell gastric lymphomas. Am J Surg Pathol 2001;25:95-102.

102 Ye H, Liu H, Raderer M, et al. High incidence of $t(11 ; 18)(q 21 ; q 21)$ in Helicobacter pylori-negative gastric MALT lymphoma. Blood 2003;101:2547-50

103 Yeh KH, Kuo SH, Chen LT, et al. Nuclear expression of BCL10 or nuclear factor kappa B helps predict Helicobacter pylori-independent status of low-grade gastric mucosa-associated lymphoid tissue lymphomas with or without $\mathrm{t}(11 ; 18)(\mathrm{q} 21 ; \mathrm{q} 21)$. Blood 2005;106:1037-41

104 Sagaert $\mathrm{X}$, de Paepe $\mathrm{P}$, Libbrecht $\mathrm{L}$, et al. Forkhead box protein $\mathrm{P} 1$ expression in mucosa-associated lymphoid tissue lymphomas predicts poor prognosis and transformation to diffuse large B-cell lymphoma. J Clin Oncol

2006;24:2490-7.
105 Liu H, Ruskon-Fourmestraux A, Lavergne-Slove A, et al. Resistance of $+(11 ; 18)$ positive gastric mucosa-associated lymphoid tissue lymphoma to Helicobacter pylori eradication therapy. Lancet 2001;357:39-40.

106 Levy M, Copie-Bergman C, Gameiro C, et al. Prognostic value of translocation $t(1) ; 18)$ in tumoral response of low-grade gastric lymphoma of mucosa-associated lymphoid tissue type to oral chemotherapy. J Clin Oncol 2005;23:5061-6.

107 Martinelli G, Laszlo D, Ferreri AJ, et al. Clinical activity of rituximab in gastric marginal zone non-Hodgkin's lymphoma resistant to or not eligible for antiHelicobacter pylori therapy. J Clin Oncol 2005;23:1979-83.

108 Streubel B, Ye H, Du $M Q$, et al. Translocation $\mathrm{t}(11 ; 18)(q 21 ; q 21)$ is not predictive of response to chemotherapy with $2 \mathrm{CdA}$ in patients with gastric MALT lymphoma. Oncology 2004;66:476-80.

109 Ott G, Katzenberger T, Greiner A, et al. The $t(11 ; 18)(q 21 ; q 21)$ chromosome translocation is a frequent and specific aberration in low-grade but not highgrade malignant non-Hodgkin's lymphomas of the mucosa-associated lymphoid tissue (MALT-) type. Cancer Res 1997;57:3944-8.

110 Ye H, Gong L, Liu H, et al. Strong BCL10 nuclear expression identifies gastric MALT lymphomas that do not respond to $\mathrm{H}$ pylori eradication. Gut 2006;55:137-8.

111 Wundisch T, Thiede C, Morgner A, et al. Long-term follow-up of gastric MALT lymphoma after Helicobacter pylori eradication. J Clin Oncol 2005;23:8018-24

112 Fischbach W, Goebeler-Kolve ME, Dragosics B, et al. Long term outcome of patients with gastric marginal zone $B$ cell lymphoma of mucosa associated ymphoid tissue (MALT) following exclusive Helicobacter pylori eradication therapy: experience from a large prospective series. Gut 2004;53:34-7.

113 Raderer M, Streubel B, Woehrer S, et al. High relapse rate in patients with MALT lymphoma warrants lifelong follow-up. Clin Cancer Res 2005: 11:3349-52.

114 Boot $H$, de Jong D. Diagnosis, treatment decisions, and follow up in primary gastric lymphoma. Gut 2002;51:621-2.

115 Copie-Bergman C, Gaulard P, Lavergne-Slove A, et al. Proposal for a new histological grading system for post-treatment evaluation of gastric MALT lymphoma. Gut 2003;52:1656.

116 Begum S, Sano T, Endo H, et al. Mucosal change of the stomach with low-grade mucosa-associated lymphoid tissue lymphoma after eradication of Helicobacter pylori: follow-up study of 48 cases. J Med Invest 2000;47:36-46.

117 Horstmann M, Erttmann R, Winkler K. Relapse of MALT lymphoma associated with Helicobacter pylori after antibiotic treatment. Lancet 1994:343:1098-9.

118 Alpen B, Robbecke J, Wundisch T, et al. Helicobacter pylori eradication therapy in gastric high grade non Hodgkin's lymphoma (NHL). Ann Hematol 2001;80(Suppl 3):B106-7.

119 Thiede C, Wundisch T, Alpen B, et al. Long-term persistence of monoclonal B cells after cure of Helicobacter pylori infection and complete histologic remission in gastric mucosa-associated lymphoid tissue B-cell lymphoma. J Clin Oncol 2001; 19:1600-9.

120 de Mascarel A, Ruskone-Fourmestraux A, Lavergne-Slove A, et al. Clinical, histological and molecular follow-up of 60 patients with gastric marginal zone lymphoma of mucosa-associated lymphoid tissue. Virchows Arch 2005;446:219-24.

121 Montalban C, Santon A, Redondo C, et al. Long-term persistence of molecular disease after histological remission in low-grade gastric MALT lymphoma treated with $\mathrm{H}$. pylori eradication. Lack of association with translocation $t(1,18)$ : a 10-year updated follow-up of a prospective study, Ann Oncol 2005; 16:1539-44.

122 Wotherspoon AC, Isaacson PG. Synchronous adenocarcinoma and low grade B-cell lymphoma of mucosa associated lymphoid tissue (MALT) of the stomach. Histopathology 1995;27:325-31.

123 Goteri G, Ranaldi R, Rezai B, et al. Synchronous mucosa-associated lymphoid tissue lymphoma and adenocarcinoma of the stomach. Am J Surg Pathol 1997;21:505-9.

124 Raderer M, Puspok A, Stummvoll G, et al. Early cancer of the stomach arising after successful treatment of gastric MALT lymphoma in patients with autoimmune disease. Scand J Gastroenterol 2003;38:294-7.

125 Morgner A, Miehlke S, Stolte M, et al. Development of early gastric cancer 4 and 5 years after complete remission of Helicobacter pylori associated gastric low grade marginal zone B cell lymphoma of MALT type. World J Gastroenterol $2001 ; 7: 248-53$

126 Copie-Bergman C, Locher C, Levy M, et al. Metachronous gastric MALT lymphoma and early gastric cancer: is residual lymphoma a risk factor for the development of gastric carcinoma? Ann Oncol 2005;16:1232-6. 